EXTENDED REPORT

\title{
Involvement of neurotrophins and their receptors in spondyloarthritis synovitis: relation to inflammation and response to treatment
}

\author{
M Rihl, E Kruithof, C Barthel, F De Keyser, E M Veys, H Zeidler, D T Y Yu, J G Kuipers, \\ D Baeten
}

See end of article for authors' affiliations

Correspondence to: Dr M Rihl, Hannover Medical Śchool (MHH), Department of Rheumatology (OE 6850), Carl-Neuberg-Str 1 30625 Hannover, Germany; Rihl.Markus@ MH-Hannover.de

Accepted 3 April 2005 Published Online First 7 April 2005
Objective: To investigate whether expression of the four members of the neurotrophin (NT) family and their four corresponding receptors is related to synovial inflammation in patients with spondyloarthritis (SpA). Material and Methods: Synovial fluid (SF) and serum NTs and their receptors were measured by ELISA. Immunohistochemistry was used for synovial tissue biopsy specimens from patients with SpA, rheumatoid arthritis, and osteoarthritis (OA). In SpA synovium, immunoreactivity of the receptors trkA and NGFRp75 was also assessed before and after 12 weeks of treatment with the monoclonal anti-tumour necrosis factor $\alpha$ antibody, infliximab.

Results: mRNA transcripts of all NTs and receptors were expressed in the inflamed synovium. At the protein level, brain derived neurotrophic factor and NT-3 were significantly higher in the SF of patients with SpA than in those with OA. In contrast, ELISA of serum samples showed that the highest member in SpA was NT-4. Immunohistochemistry demonstrated that the NT receptors trkA and NGFRp75 were highly expressed in the inflamed synovium of patients with SpA, correlating with vascularity and lymphoid aggregates, respectively. Additionally, immunoreactivity of both receptors was significantly decreased after infliximab treatment.

Conclusions: NTs and their receptors are expressed in inflamed peripheral joints of patients with SpA. Their expression is not constitutive but related to inflammation and they may be involved in the local disease processes.
W e have previously validated cDNA based microarrays as a screening approach to identify and further explore potential pathogenic mediators of synovitis in spondyloarthritis (SpA). ${ }^{12}$ Recent data suggest the up regulation of neurotrophins (NTs) and their receptors in SpA. ${ }^{3}$ NTs are secreted growth factors exerting essential functions such as proliferation, survival, and differentiation of cells within the mammalian nervous system upon binding to, and dimerising of, specific tyrosine kinase receptors. ${ }^{4}$ To date, nerve growth factor (NGF), brain derived neurotrophic factor (BDNF), neurotrophin-3 (NT-3), and NT-4 have been identified in humans. Their specific high affinity receptors are trkA (for NGF), trkB (for BDNF and NT-4), and trkC (for NT3). All NTs also bind to a common low affinity receptor, NGFRp75, signalling independently from the trk receptors. ${ }^{4}$

Over the past decade, substantial evidence has demonstrated the expression of NTs in non-neural tissues. ${ }^{4}$ One major source for NTs and their receptors outside the nervous system appears to be cells of the haematopoietic/immune system as well as the skeletal/connective tissue system. ${ }^{5-11}$ Indeed, expression of NGF and its high affinity receptor (trkA) has been described in arthritic synovium and chondrocytes. ${ }^{512} 13$ Although this may be related to neural alterations such as the reduction of sympathetic innervation of inflamed synovium, ${ }^{514}$ an increasing body of evidence suggests a functional role for NTs and their receptors in immune mediated inflammatory diseases. ${ }^{16}{ }^{17}$

This study aimed at determining the expression of NTs and their receptors in peripheral synovitis of patients with SpA and exploring their potential involvement in the inflammatory disease processes.

\section{PATIENTS AND METHODS \\ Patients}

Table 1 gives the clinical data of the 49 patients. The study group comprised 24 patients with SpA fulfilling the European Spondylarthropathy Study Group classification criteria, ${ }^{18} 15$ patients with RA fulfilling the American College of Rheumatology classification criteria $^{19}$ who were included as inflammatory comparison, and 10 patients with osteoarthritis (OA) as non-inflammatory comparison. Nine of the 24 patients with SpA were treated with the monoclonal antitumour necrosis factor $\alpha(\mathrm{TNF} \alpha)$ antibody, infliximab ( $5 \mathrm{mg} /$ $\mathrm{kg}$ intravenously at baseline, week 0 , and week 6), as described previously. ${ }^{20}$ In these patients synovial tissue (ST) samples were obtained at baseline and at week 12 of treatment. Written informed consent was obtained before entering the study as approved by the local ethics committee.

\section{Synovial tissue and fluid samples}

In all patients, ST biopsy specimens and synovial fluid (SF) samples were obtained by needle arthroscopy of an actively inflamed knee joint, as described earlier. ${ }^{21}$ Because we previously demonstrated that the global histopathological features of the synovium are identical in the various SpA subgroups, ${ }^{22}{ }^{23}$ we considered the SpA samples ( 8 ankylosing spondylitis, 6 psoriatic arthritis, and 10 undifferentiated SpA) collectively as one group. In the patients receiving anti-TNF $\alpha$

Abbreviations: BDNF, brain derived neurotrophic factor; ELISA, enzyme linked immunosorbent assay; NGF, nerve growth factor; NT, neurotrophin; OA, osteoarthritis; PCR, polymerase chain reaction; RA, rheumatoid arthritis; SF, synovial fluid; SpA, spondyloarthritis; ST, synovial tissue; TNF $\alpha$, tumour necrosis factor $\alpha$ 
Table 1 Demographic and clinical data from the 49 patients included in the study: 24 patients with $\mathrm{SpA}, 15$ with rheumatoid arthritis (RA), and 10 with $\mathrm{OA}$

\begin{tabular}{|c|c|c|c|c|c|c|}
\hline \multirow[b]{2}{*}{ Data } & \multicolumn{2}{|c|}{$\operatorname{SpA}(n=24)$} & \multicolumn{2}{|c|}{ RA $(n=15)$} & \multicolumn{2}{|c|}{$O A(n=10)$} \\
\hline & Mean & (range) & Mean & (range) & Mean & (range) \\
\hline Age (years) & 47 & $(19-66)$ & 63 & $(40-74)$ & 62 & $(29-87)$ \\
\hline $\operatorname{Sex}(M / F)$ & $18 / 6$ & & $8 / 7$ & & $5 / 5$ & \\
\hline Disease duration (years) & 3 & $(0.1-42)$ & 2 & $(0.1-20)$ & 2 & $(0.1-35)$ \\
\hline HLA-B27 (+/-) & $12 / 12$ & & NA & & NA & \\
\hline Swollen joint count & 2 & $(1-24)$ & 6 & $(1-25)$ & 1 & $(1-2)$ \\
\hline CRP (mg/l) & 22 & $(4-167)$ & 60 & $(16-550)$ & 0 & (0-72) \\
\hline $\operatorname{ESR}(\mathrm{mm} / 1 \mathrm{st} h)$ & 24 & (3-101) & 48 & $(7-90)$ & 4 & $(1-37)$ \\
\hline Lining $^{*}$ & 1 & $(1-2)$ & 1 & $(1-3)$ & 1 & $(1-2)$ \\
\hline Vascularisation* & 2 & (1-3) & 1.3 & $(1-2.5)$ & 1 & $(0-2)$ \\
\hline Infiltration* & 2 & $(0-3)$ & 2 & $(0.5-3)$ & 0.5 & $(0-1)$ \\
\hline Lymphoid aggregates* & 0.5 & $(0-2)$ & 1 & $(1-2)$ & 0 & $(0-1)$ \\
\hline Plasma cells* & 0 & $(0-3)$ & 0.3 & $(0-2)$ & 0 & (0) \\
\hline Polymorphonuclear cells* & 0 & $(0-3)$ & 0 & $(0-2.5)$ & 0 & (0) \\
\hline CD3+* ${ }^{*}$ & 1.5 & $(0-3)$ & 2 & $(0-3)$ & 1 & $(0-3)$ \\
\hline $\mathrm{CD} 20+^{*}$ & 1 & $(0-3)$ & 2 & $(0-2.5)$ & 0 & $(0-2)$ \\
\hline
\end{tabular}

All patients had active disease with at least one swollen knee joint. Among the 24 patients with SpA, nine were studied also after 12 weeks of treatment with the monoclonal anti-TNF $\alpha$ antibody, infliximab.

*The following synovial histology parameters were evaluated: lining, microscopic evaluation of the lining layer thickness ranging from 1 (layer of $1-2$ cells) to 2 (layer of $4-5$ cells) to 3 (layer of $>5$ cells); vascularisation, degree of vascularisation scored from 0 to 3 ; infiltration, degree of cellular infiltration scored from 0 to 3 ; lymphoid aggregates, presence of lymphoid aggregates scored from 0 (absent) to 1 (present); plasma cells, presence of plasma cells scored from 0 (absent) to 3 (multiple cells within the entire synovium); polymorphonuclear cells, presence of polymorphonuclear cells within the synovium scored from 0 (absent) to 3 (multiple cells within the entire synovium); immunoreactivities of CD3+, T cell marker (anti-CD3 monoclonal antibody, DAKO), and CD20+, B cell marker (anti-CD20 monoclonal antibody, DAKO) were graded from 0 to 3.

treatment, synovial biopsy samples were obtained at baseline and after 12 weeks of treatment. Histological inflammation was assessed by two independent observers, scoring semiquantitatively the lining layer thickness, vascularity, global inflammatory infiltration, lymphoid aggregates, polymorphonuclear cells, plasma cells, CD3+ T lymphocytes, and CD20+ B lymphocytes as extensively described previously (table 1). ${ }^{2024}$

\section{Real time polymerase chain reaction (PCR; Taqman assay)}

TRizol reagent (Life Technologies, Eggenstein/Germany) was used to extract total RNA from synovial biopsy specimens of four patients: two with SpA and two with RA. Generation of cDNA by reverse transcription and use of the Taqman assay was carried out according to the manufacturer's protocol. Assays on demand for NGF $\beta$ (assay-ID Hs00171458), BDNF (Hs00156058), NT-3 (Hs00267375), and an assay by design for NT-4 (catalogue No 4332078) as well as assays on demand for the receptors trkA (Hs00176787), trkB (Hs00178811), trkC (Hs00176797), and NGFRp75 (Hs00609976) were purchased from Applied Biosystems (Warrington, UK).

\section{Quantitative immunoassay (ELISA)}

Quantitative sandwich enzyme immunoassay kits were purchased from R\&D Systems (Abingdon, UK). Concentrations of the neurotrophic factors NGF (catalogue No DY256), BDNF (DBD00), NT-3 (DY267), and NT-4 (DY268) were measured in the synovial fluid samples of 15 patients with SpA, 15 with RA, and 10 patients with OA described in table 1 . For comparison, paired serum samples of the patients as well as serum from 10 healthy subjects were used as controls.

\section{Immunohistochemistry}

Immunohistochemistry was performed on frozen ST sections to determine the immunoreactivity in the synovial lining layer, the sublining layer, and the endothelium of the high affinity receptor trkA (anti-trkA rabbit polyclonal antibody, clone sc-7268; Santa Cruz/CA) and the low affinity receptor NGFRp75 (anti-NGFRp75 monoclonal mouse antibody, clone M3507; DAKO, Glostrup, Denmark) in 24 patients with SpA, 15 with RA, and 10 with OA. Immunohistochemical staining was performed using the LSAB+ kit (Dako) and was scored by two independent observers in a blinded fashion on a scale from 0 (no staining intensity) to 3 (maximum staining intensity). This scoring method has been extensively described and validated previously. 2024

To determine a potential modulation of the two NT receptors by the monoclonal anti-TNF antibody infliximab, we stained for trkA and NGFRp75 in ST biopsy specimens obtained before and 12 weeks after treatment in 9/24 patients with SpA (table 1). Stained sections were blinded for patients (not pairwise) and time of sampling and scored by two independent observers.

\section{Statistical analysis}

Between-group comparison was performed with the unpaired or paired (for the pre- and post-infliximab samples, respectively) non-parametric Mann-Whitney $U$ test as appropriate. Correlation coefficients within one group were determined using Spearman's correlation $\left(r_{\mathrm{s}}\right)$ matrices, as appropriate, for non-parametric data. The level of significance was defined as $\mathrm{p}<0.05$.

\section{RESULTS}

\section{NT and NT receptor $m$ RNA is expressed in the inflamed synovium}

All four NTs and all four receptors were found to be expressed in inflammatory synovium samples obtained from two patients with SpA and two with RA (data not shown). Highest levels were measured for NGF and NT-3 (up to 8500fold) and for trkB, trkC, and NGFRp75 (up to 8800-fold) in both SpA and RA as compared with peripheral blood mononuclear cells of four healthy subjects. However, mRNA of NT-4 and trkA were expressed at lower levels (up to 15 -fold). Although this analysis did not aim at comparing SpA and RA quantitatively, it confirmed the presence of NT mRNA in the inflamed synovium of both diseases. 

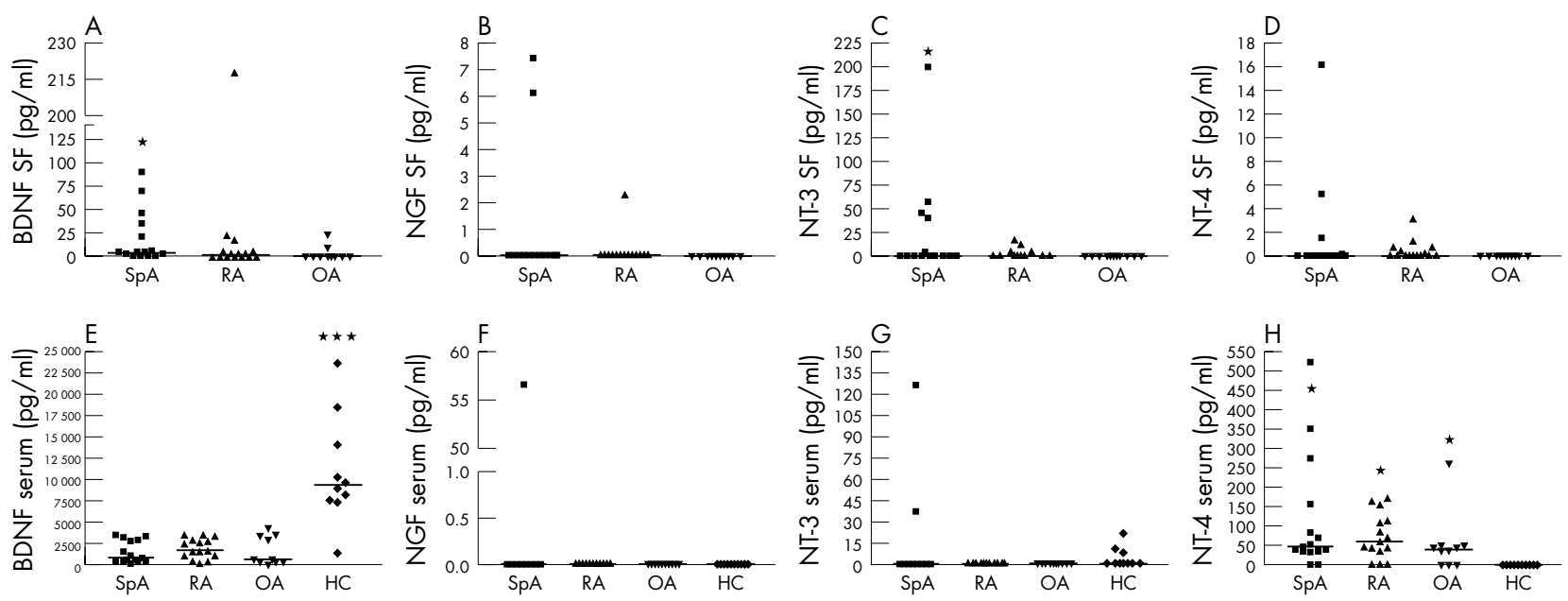

Figure 1 Neurotrophins were measured by quantitative immunoassay in the SF of 15 patients with SpA, 15 with RA, and 10 with OA (A-D) and in the serum of these patients and 10 healthy controls $(\mathrm{HC})(\mathrm{E}-\mathrm{H})$. The scatter plots of all four neurotrophins indicate the individual values. Bold horizontal lines represent the median. Detectable concentrations (median, range; always given for the total group of patients) of SF BDNF were measured in 11 / $15(73 \%)$ patients with SpA $(4.5 \mathrm{pg} / \mathrm{ml}, 0-90)$, in $8 / 15(53 \%)$ patients with RA $(1.7 \mathrm{pg} / \mathrm{ml}, 0-218)$, and in $2 / 10(20 \%)$ patients with OA $(0 \mathrm{pg} / \mathrm{ml}, 0$ 24). SF BDNF concentrations were significantly higher in the SpA group than in patients with OA (A), ${ }^{*} \mathrm{p}=0.025$. SF NT-3 was detected in $5 / 15$ (33\%) patients with SpA $(0 \mathrm{pg} / \mathrm{ml}, 0-200)$ and in $4 / 15(27 \%)$ patients with RA $(0 \mathrm{pg} / \mathrm{ml}, 0-17)$. SF NT-3 levels were also significantly higher in SpA than in OA $\left.(C),{ }^{*} p=0.047\right)$. Serum BDNF (E) was detectable in all 50 subjects showing significantly higher levels in $H C$ than all the other groups (SpA, ${ }^{*} p<0.0001$; RA, ${ }^{*} p<0.0001$; and OA, $\left.{ }^{*} p=0.001\right)$, whereas serum NT-4 (H) was significantly higher in $\mathrm{SpA}\left({ }^{*} p<0.001\right), \mathrm{RA}\left({ }^{*} p=0.001\right)$, and $\mathrm{OA}$ $\left({ }^{*} \mathrm{p}=0.008\right)$ than in $\mathrm{HC}$.

\section{SF levels of BDNF and NT-3 are raised in SpA}

To investigate at the protein level whether NTs were present in the inflamed joint, we measured their concentration in SF samples by enzyme linked immunosorbent assay (ELISA). Figures 1A-D show individual values depicted by four scatter plots for each NT. Detectable concentrations of BDNF were measured in most patients with SpA showing significantly higher concentrations than in patients with OA $(\mathrm{p}=0.025)$.
Additionally, NT-3 was significantly higher in SpA than in OA $(p=0.047)$. The other two NTs were detectable only in a minority of samples.

To investigate whether NTs were expressed only locally or also found in the serum, we analysed their concentration in the serum of all patients using paired SF and serum samples and also in 10 samples of healthy controls. Individual values are depicted again by four scatter plots (figs 1E-H). NT-4 was
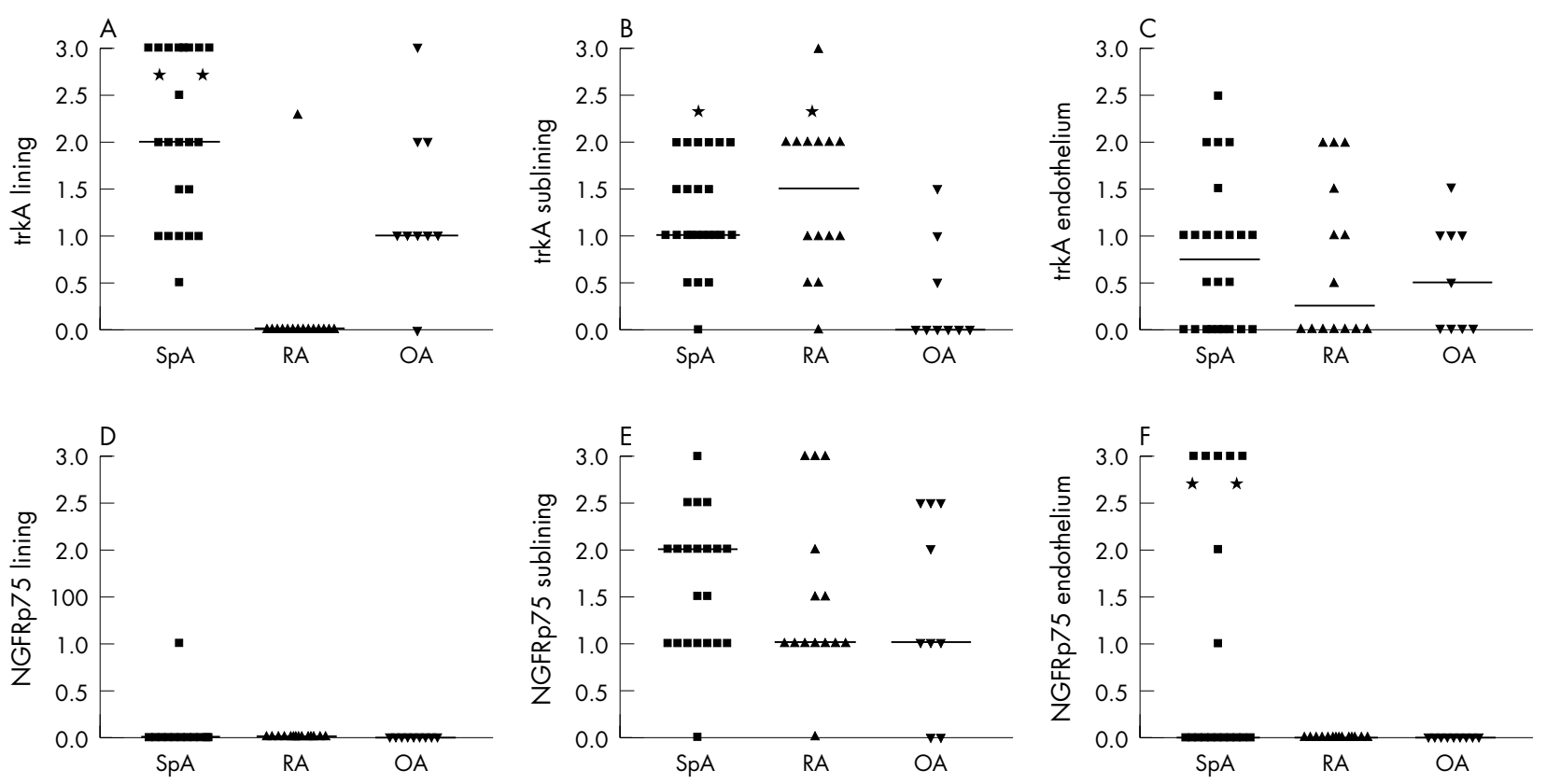

Figure 2 Immunoreactivity of trkA (A-C) and NGFRp75 (D-F) in the lining layer, sublining layer, and endothelium of synovial tissue biopsy specimens obtained from clinically affected knee joints of 24 patients with SpA, 15 with RA, and 10 with OA. The results represent the individual scores on a semiquantitative $O$ (no expression) to 3 (high expression) scale, with bars representing the median score. As indicated (*), the immunoreactivity of trkA was significantly higher in SpA lining than in RA lining $(p=0.047)$ and OA lining $(p=0.034)$. Similarly, trkA was more highly expressed in SpA and RA sublining than in OA ( $p=0.001$ and $p=0.003$, respectively). NGFRp75 was almost absent in the lining layer and was equally expressed across disease groups in the sublining layer. However, some patients with SpA showed high endothelial expression, resulting in a significant difference in comparison with RA $(p=0.012)$ and $O A(p=0.041)$. 


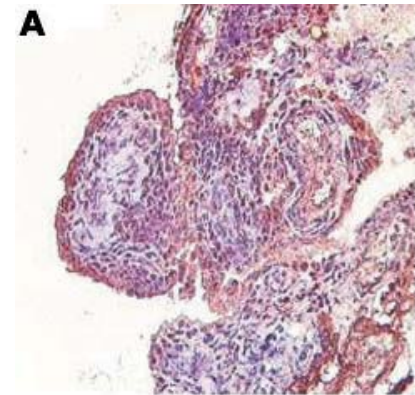

SpA, trkA

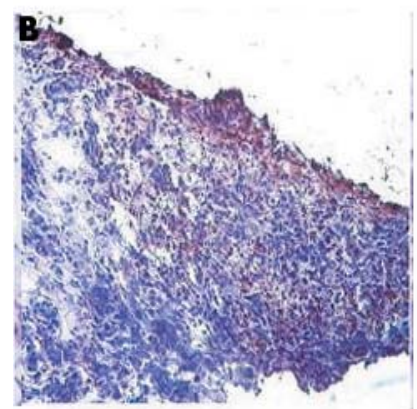

RA, trkA

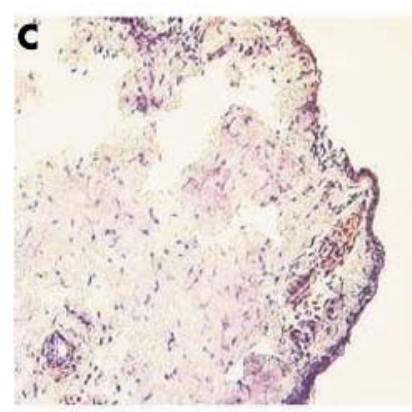

OA, trkA

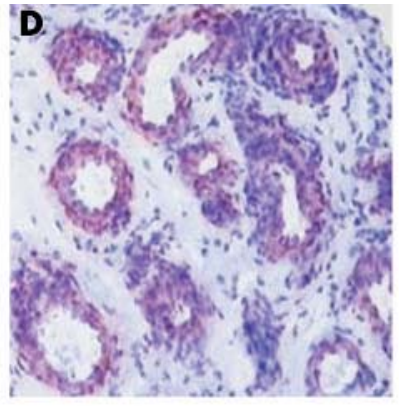

SpA, trkA

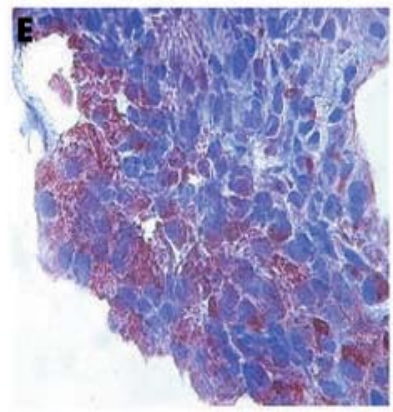

RA, trkA

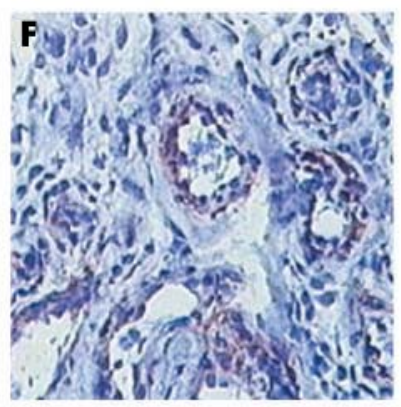

OA, trkA

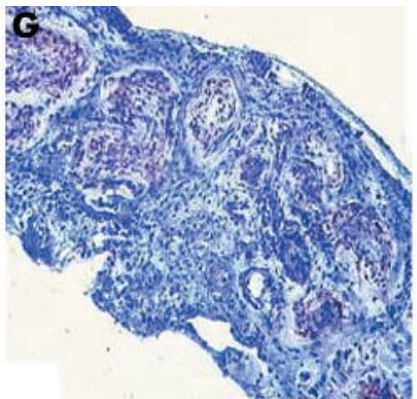

SpA, NGFRp75

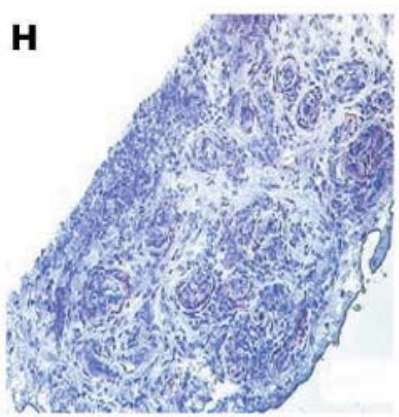

RA, NGFRp75

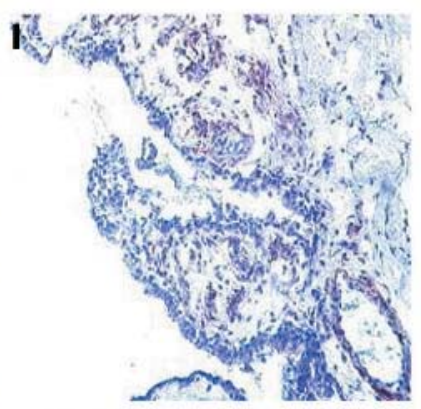

OA, NGFRp75
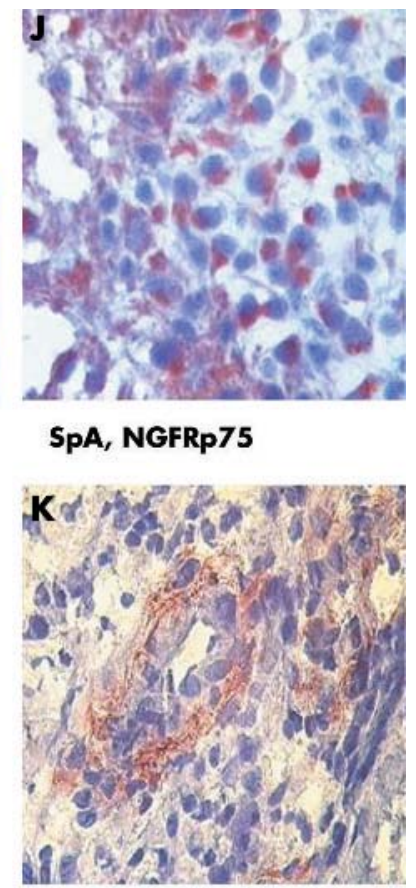

RA, NGFRp75

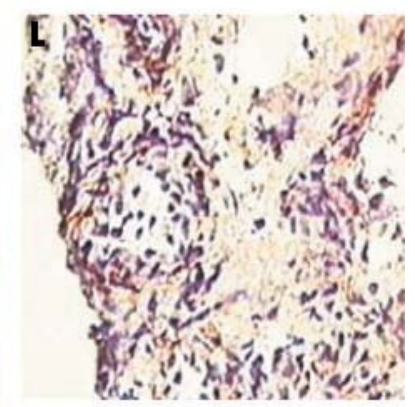

OA, NGFRp75

Figure 3 Microscopic pictures of ST sections from 12 different patients are depicted. (A-F) immunostaining of synovial tissue samples of two different patients with $S p A, R A$, and $O A$ each at low $(A, B, C, \times 160)$ and high magnification $(D, E, F, \times 320)$. In patients with $S p A$, intensive trkA staining predominantly in the lining layer (A) and less intense staining in the sublining layer and the endothelium (D) is seen. In patients with RA, a similar pattern for trkA staining is seen $(B, \times 160$ and $E, \times 320)$ and correspondingly for patients with $O A(C, F)$. (G-L) NGFRp75 immunoreactivity showing an intense staining in the sublining layer $(G, J)$ of patients with $S p A$. However, immunoreactivity for NGFRp75 is less intense in RA $(H, K)$ and OA $(I, L)$ than in SpA. In all three groups, NGFRp75 staining is not seen in the lining layer, but it is found in the endothelium of patients with SpA.
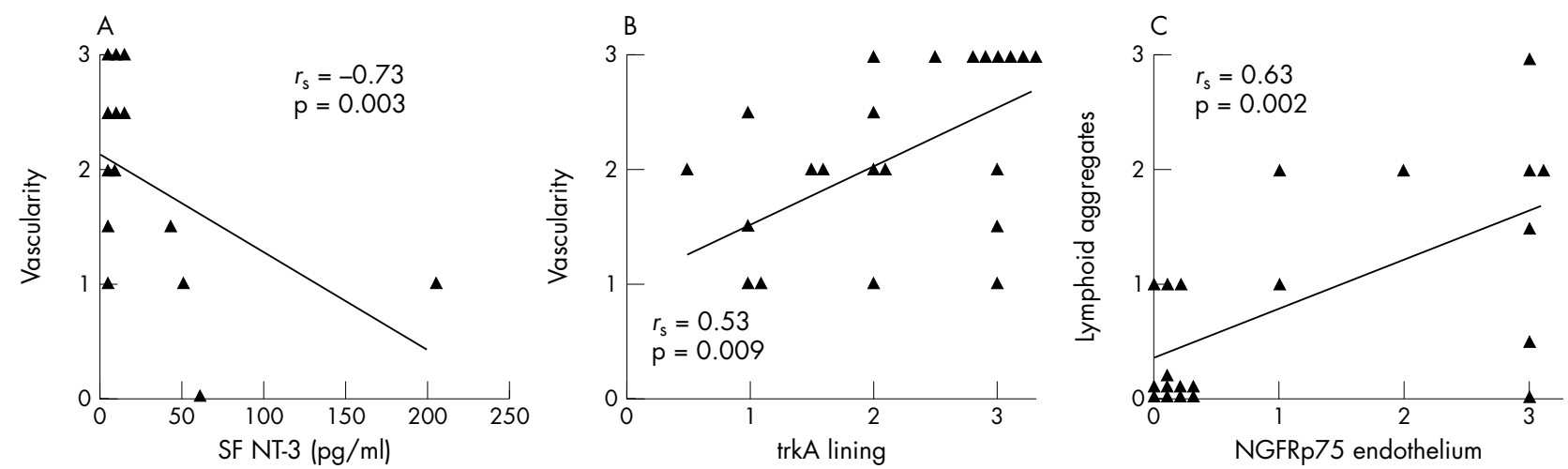

Figure 4 Significant correlations as determined by Spearman's test in patients with SpA between NT expression and measures of synovial inflammation were found for (A) NT-3 in SF and the degree of vascularisation; (B) immunoreactivity of trkA in the lining layer and the degree of vascularisation; and (C) immunoreactivity of NGFR75 in the endothelium and the number of lymphoid aggregates. 
A

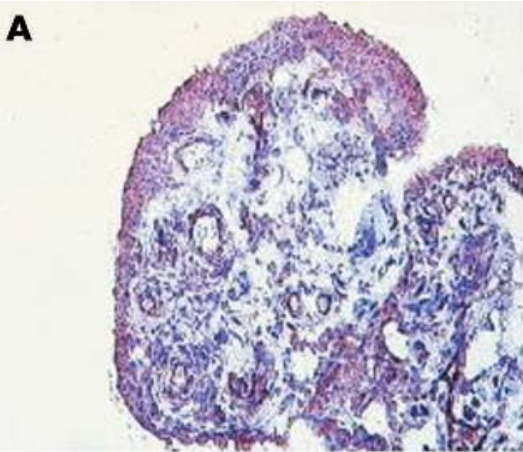

trkA - week 0

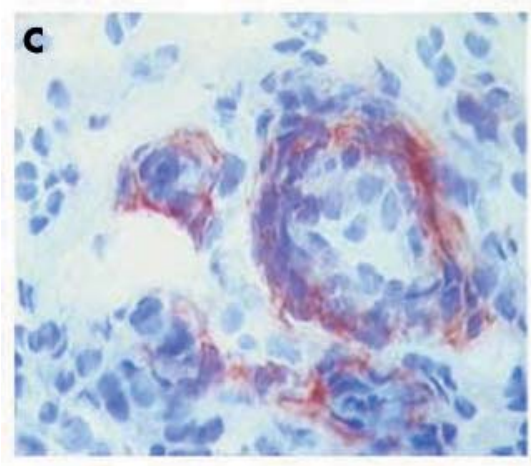

trkA - week 0

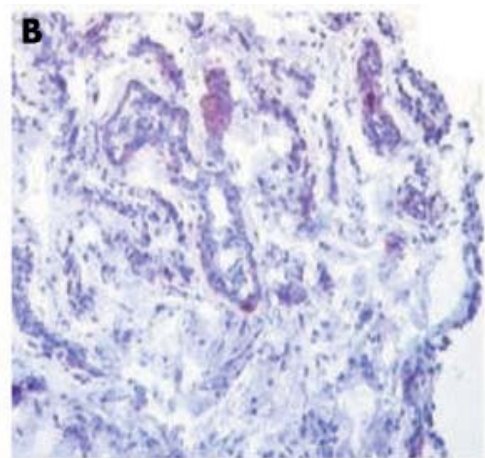

trkA - week 12
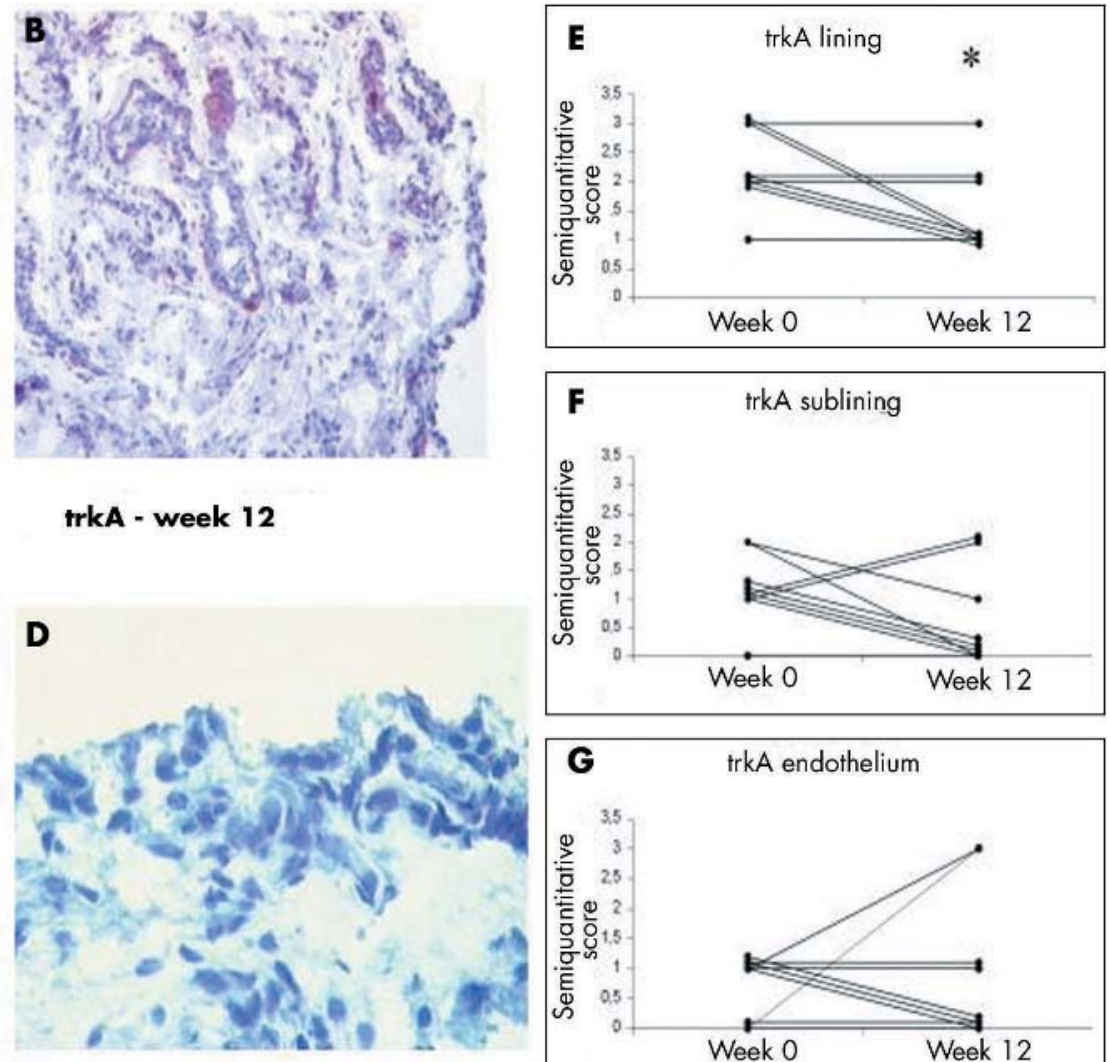

trkA - week 12

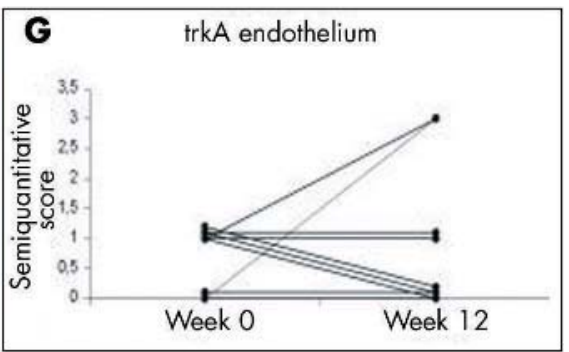

Figure 5 Immunohistochemistry on ST biopsy samples of selected patients with SpA before and after 12 weeks of infliximab treatment (original magnification is $\times 160$ in $A, B$ and $\times 320$ in $C, D)$. (A, C) show trkA staining at baseline (week 0 ) with a predominance of immunoreactivity in the lining and sublining layer. (B, D) Staining of synovial samples obtained in the same patients after 12 weeks of treatment with infliximab. (E-G) indicate the semiquantitative scores (0-3) for trkA expression in the lining and sublining layer and in the endothelium of all nine patients with SpA who were analysed before and 12 weeks after TNF $\alpha$ blocking treatment with infliximab. (E) The trkA reduction in the lining layer was significant at $p=0.03$ (*).

expressed in the majority of all samples showing significantly higher concentrations in all disease groups than in healthy controls. Surprisingly, BDNF was detected in the serum of all 50 subjects and showed the highest levels in healthy controls, which were significantly higher than in all other groups (fig 1E). None of the samples expressed important amounts of NGF or NT-3. No differences between the SpA subgroups were found for either SF or serum levels.

Correlations of NTs between serum and SF samples as determined by Spearman's test were significant in SpA for NGF $\left(r_{\mathrm{s}}=0.73, \mathrm{p}=0.002\right)$ and NT-3 $\left(r_{\mathrm{s}}=0.65, \mathrm{p}=0.008\right)$ but in none of the other groups. Taken together, these data indicate that both BDNF and NT-3 levels are raised in SpA SF, with NT-3 being found predominantly locally in the inflamed joint, whereas BDNF is also raised in serum.

\section{TrkA and NGFRp75 are highly expressed in SpA synovitis}

Using immunohistochemistry, we next analysed the synovial expression of the high affinity receptor trkA and the low affinity receptor NGFRp75 in 24 patients with SpA, 10 patients with RA, and 10 patients with OA. Figures $2 \mathrm{~A}-\mathrm{C}$ and figs $3 \mathrm{~A}-\mathrm{F}$ show that the staining for trkA was most pronounced in the lining and the sublining layer and less intensive in the endothelium. NGFRp75 staining was predominantly found in the sublining layer and to a lesser extent in the endothelium of patients with SpA (figs 2D-F; figs $3 \mathrm{G}-\mathrm{L}$ ). Comparison of the different disease groups showed that trkA immunoreactivity in the lining layer was significantly higher in SpA than in RA and OA $(\mathrm{p}=0.047$ for SpA $v$ RA and $\mathrm{p}=0.034$ for SpA $v$ OA). There was no difference for lining layer hyperplasia between these groups, which emphasises the specificity of this finding (table 1 ). Moreover, trkA in the sublining layer was significantly higher in SpA $v$ OA as well as in RA $v$ OA $(p=0.001$ and $p=0.003$, respectively). Additionally, NGFRp75 in the endothelium was significantly higher in SpA than in RA and OA $(p=0.012$ and $p=0.041$, respectively), which may be related to the higher degree of global vascularity in SpA (table 1). No differences in trkA or NGFRp75 expression were found between the SpA subgroups.

\section{Correlation of NTs and their receptors with local inflammation in SpA synovitis}

Because both NTs (BDNF and NT-3) and NT receptors (trkA and NGFRp75) appeared to be highly expressed in SpA synovitis, we then analysed whether their expression in patients with SpA $(\mathrm{n}=15$ for ELISA data, $\mathrm{n}=24$ for immunohistochemistry data) correlated with measures of synovial inflammation. Interestingly, SF NT-3 levels correlated inversely with the degree of vascularisation $\left(r_{\mathrm{s}}=-0.73\right.$; $\mathrm{p}=0.003)$. For the receptors, significant correlations were found for trkA in the lining layer and the degree of vascularisation $\left(r_{\mathrm{s}}=0.53 ; \mathrm{p}=0.009\right)$ and for NGFRp75 in the endothelium and the number of lymphoid aggregates $\left(r_{\mathrm{s}}=0.63 ; \mathrm{p}=0.002\right)($ fig 4$)$. 
A

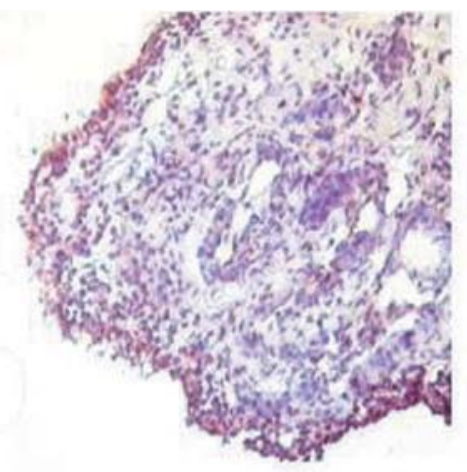

NGFRp75 - week 0

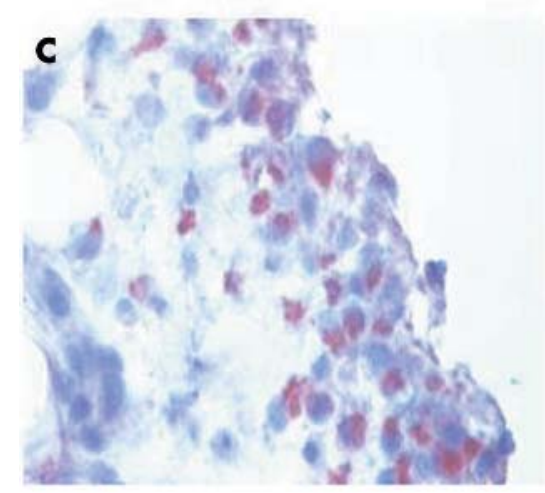

NGFRp75 - week 0
B

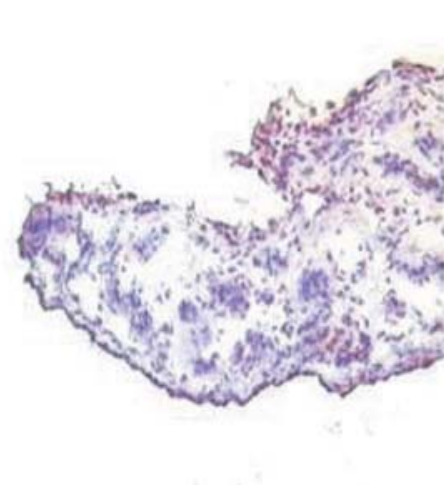

NGFRp75 - week 12

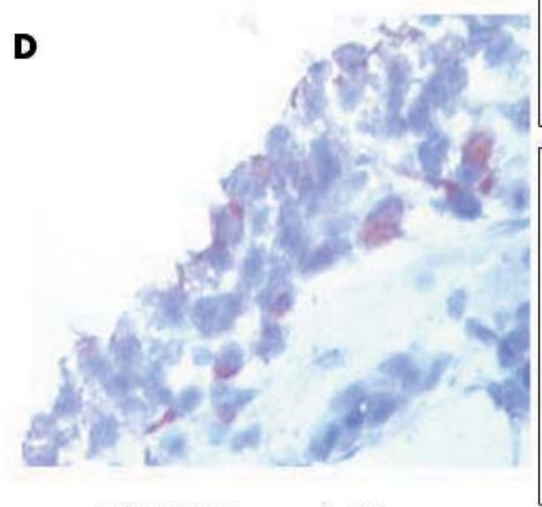

NGFRp75 - week 12

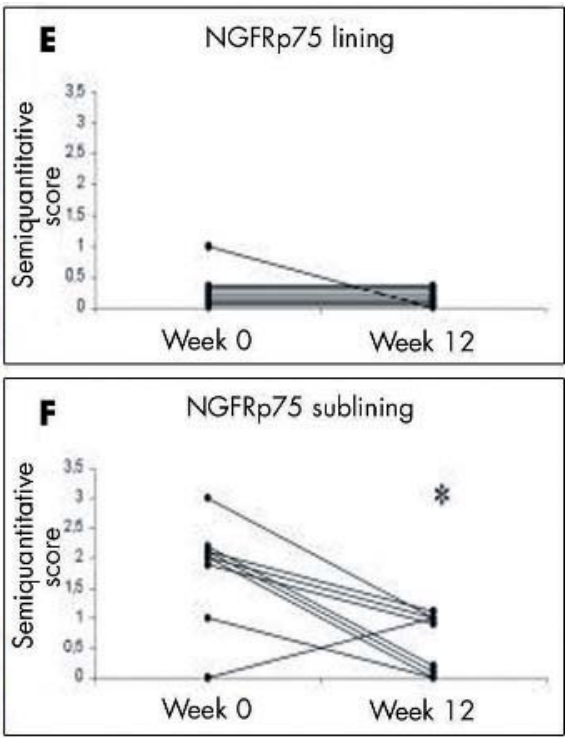

G NGFRp75 endothelium

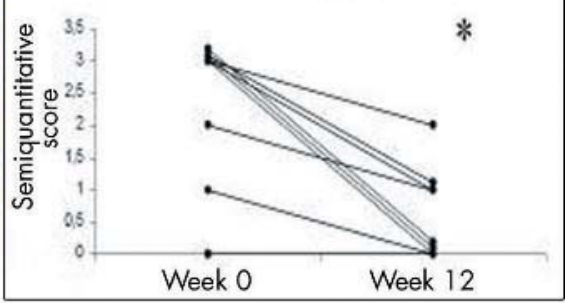

Figure 6 Immunohistochemistry on ST biopsy specimens of selected patients with SpA before and after 12 weeks of infliximab treatment (original magnification is $\times 160$ in A, B and $\times 320$ in C, D). (A, C) NGFRp75 staining at baseline, with a predominance in the sublining layer and the endothelium. (B, D) Synovial sections of the same patients stained after 12 weeks of anti-TNF $\alpha$ treatment with infliximab, showing clearly a less intense or even absent staining in both the lining and the sublining layer as well as in the endothelium. (E-G) indicate the semiquantitative scores (0-3) of NGFRp75 expression in the lining and sublining layer and in the endothelium of the nine patients with SpA before and 12 weeks after TNF $\alpha$ blocking treatment with infliximab. $(F, G)$ NGFRp75 is significantly reduced in the sublining layer and in the endothelium (both at * $p=0.004$ ).

\section{TrkA and NGFRp75 immunoreactivity is down regulated by anti-TNFa treatment}

Because the high expression in SpA synovitis and the correlations with measures of local inflammation suggested that the synovial NT receptor expression was related to local inflammation, we analysed whether trkA and NGFRp75 expression could be modulated by TNF $\alpha$ blockade in vivo. The immunohistochemistry procedure used here is identical to that described for data depicted in figs 2 and 3. Figure 5 shows that trkA immunoreactivity was most intense in the lining layer at baseline and was significantly reduced after 12 weeks of treatment (median (range) $2(1-3) \vee 1(1-3)$; $\mathrm{p}=0.03$ ), whereas staining in the sublining layer and the endothelium was not significantly altered over this period. For NGFRp75, immunoreactivity was significantly reduced in the sublining layer $(2(0-3) \vee \mathrm{l}(0-1) ; \mathrm{p}=0.004)$ and in the endothelium $(2(0-3) \vee 0(0-2) ; \mathrm{p}=0.004)$ (fig 6).

\section{DISCUSSION}

We have previously identified NTs and their receptors as being expressed in SpA synovitis using cDNA based microarrays. $^{3}$ Because recent studies suggest that this system may also have a role in immunity, inflammation, and infection, ${ }^{25-27}$ and because we recently demonstrated that candidate mediators identified by microarray may turn out to be important factors in SpA inflammation, ${ }^{2}$ this study aimed at providing detailed evidence that NTs and their receptors are expressed in SpA synovitis.

Although the aim of the PCR experiments was to confirm the expression at the mRNA level in ST rather than to make quantitative comparisons, it seemed that NT-3, BDNF, trkB, and trkC were highly expressed, whereas NT-4 and trkA were expressed at lower levels. In parallel with these findings, quantitative immunoassay indicated the presence of BDNF and NT-3 but not NT-4 and NGF in SF. Although these data do not exclude the possibility that the different factors are expressed in the ST itself rather than in the SF, they indicate the local presence of BDNF and NT-3 proteins in the inflamed SpA joint. Both NTs were at a higher level and more frequently detected in the SF of SpA than in OA.

Interestingly, BDNF levels were higher in serum than in $\mathrm{SF}$, with the highest concentrations being found in the serum of healthy subjects. Although this is in agreement with previous reports on serum BDNF levels, ${ }^{28-30}$ it might suggest that BDNF diffuses from serum rather than being produced locally. However, this hypothesis does not fit with the presence of mRNA in ST, with the higher SF levels in an inflammatory disease such as SpA versus OA, with the absence of correlation between BDNF levels in serum and SF, and with the presence of NT-4 in serum, which obviously does not diffuse to the SF in the same subjects. For NT-3, the situation is more clear cut because it was detected more 
frequently and at higher levels in SF than in serum, suggesting local production.

The presence of at least BDNF and NT-3 in the inflamed SpA joint raises the possibility that they exert a local effect through interaction with their receptors. Both PCR and immunohistochemistry confirmed the extensive presence of the receptors in the inflamed SpA joint, which in turn extends previous studies demonstrating up regulation of trkA expression in experimental arthritis models, ${ }^{12}$ in human osteoarthritic chondrocytes, ${ }^{7}$ and in the human rheumatoid synovium. ${ }^{5}$ Our staining showed a different pattern for the high affinity NGF receptor trkA, which was extensively found in the lining layer as well as in the sublining layer, and the low affinity NGFRp75 receptor, which was found predominantly in the sublining layer and the endothelium. Several studies indicate a generally lower expression of NGFRp75 than of the high affinity receptor trkA. ${ }^{12} 3132$ Interestingly, the immunoreactivity in the synovial membrane was clearly distinct for the two receptors. Indeed, the increased expression of both NTs and their receptors in chronic autoimmune arthritis, and especially in SpA, and also the distinct expression pattern of the two receptors raise the possibility that they have a biological role in SpA synovitis. A functional role for trkA, the high affinity NGF receptor, has not been demonstrated in arthritis so far but has been recently demonstrated in psoriasis: a pharmacological blocking agent as well as NGF neutralising antibodies clearly inhibited the disease in a mouse model. ${ }^{33}$ In addition, NGF and trkA seem to have a pathogenic role in allergic bronchial asthma. ${ }^{16}$ Consistent with these data in other immune mediated inflammatory diseases, we found evidence in our study of a correlation between the expression of the NT receptors and histological parameters of inflammation, such as vascularity and the presence of lymphoid aggregates, in SpA synovium. Expression of these receptors is not constitutive but is actively modulated in relation to inflammation in vivo as was further demonstrated by the significant reduction of immunoreactivity of the two receptors by effective pharmacological treatment with infliximab. Together, these data indicate that reduction of synovial inflammation by anti-TNF $\alpha$ treatment is paralleled by a profound down regulation of the NT receptor expression.

It is interesting to note that in a previous study, NGF and trkA were found to be activated by lipopolysaccharide incubation in healthy human monocytes/macrophages. ${ }^{34}$ When neutralising anti-NGF antibody was added, massive apoptosis of the cells was noted, suggesting that NGF is an autocrine survival factor for monocytes/macrophages in infection and inflammation. Similar observations were reported in virally infected monocytes, mast cells, and memory B lymphocytes. ${ }^{25} 2635$ Considering the pronounced role of macrophages in SpA inflammation and their reduction by anti-TNF $\alpha$ treatment, this might be one of the mechanisms linking NTs to synovial inflammation. ${ }^{36-39}$ However, their role is likely to be much more complex, including antiinflammatory and protective aspects, as suggested for NGF and NT-3 in experimental colitis. ${ }^{40}{ }^{41}$ Another function attributed to NTs may also include tissue repair/remodelling capacities. It has been suggested that NGF, in particular, plays a part in wound healing, fibrosis, and treatment of vascular and corneal ulcers. ${ }^{35}{ }^{42-44}$

In conclusion, this study demonstrates the presence both of NTs and their receptors in peripheral SpA synovitis. We also provide in vivo evidence that the expression of these mediators is not constitutive and may be directly or indirectly related to the inflammatory disease process. NTs and their receptors may function as potential immunomodulatory mediators and warrant further investigation in SpA.

\section{ACKNOWLEDGEMENTS}

The work of Markus Rihl was supported by the Rheumatology Competence Network, Berlin and the Deutsche Forschungsgemeinschaft (DFG, RI 119/1-1). Jens G Kuipers was supported by research grants from Hannover Medical School (HiLF programme), DFG KU1182/1-and 1-3; BMBF 01VM9305; BMBF 01 GI 9950, Deutsche Stiftung für Herzforschung; Gesellschaft der Freunde der Medizinischen Hochschule Hannover; BIOMED BMH4CT-98-3605, and QLRI-CT-2002-02276. Dominique Baeten is supported by the Fund for Scientific Research, Flanders (FWOVlaanderen). This work was also supported by the Nora Eccles Treadwell Foundation at UCLA.

\section{Authors' affiliations}

M Rihl, C Barthel, H Zeidler, J G Kuipers, Hannover Medical School

$(\mathrm{MHH})$, Department of Rheumatology, Hannover, Germany

E Kruithof, F D Keyser, E M Veys, D Baeten, Ghent University Hospital, Department of Rheumatology, Ghent, Belgium

D T Y Yu, University of California Los Angeles (UCLA), Division of Rheumatology, Los Angeles, CA, USA

J G Kuipers, Rotes Kreuz Krankenhaus, Department of Rheumatology, Bremen, Germany

\section{REFERENCES}

1 Rihl M, Baeten D, Seta N, Gu J, De Keyser F, Veys EM, et al. Technical validation of cDNA based microarray as screening technique to identify candidate genes in synovial tissue biopsy specimens from patients with spondyloarthropathy. Ann Rheum Dis 2004;63:498-507.

2 Vandooren B, Kruithof E, Yu DTY, Rihl M, Gu J, De Rycke L, et al. Matrix metalloproteinases and their inhibitors are involved in peripheral synovitis and down-regulated by TNF $\alpha$ blockade in spondyloarthropathy. Arthritis Rheum 2004; 50:2942-53.

3 Yang C, Gu J, Rihl M, Baeten D, Huang F, Zhao M, et al. Serum levels of metalloproteinase-3 (MMP3) and macrophage colony-stimulating factor (MCSF-1) correlate with disease activity in ankylosing spondylitis. Arthritis Rheum 2004;51:691-9.

4 Tessarollo L. Pleiotropic functions of neurotrophins in development. Cytokine Growth Factor Rev 1998;9:125-37.

5 Pozza M, Guerra M, Manzini E, Calza L. A histochemical study of the rheumatoid synovium: focus on nitric oxide, nerve growth factor high affinity receptor, and innervation. J Rheumatol 2000;27:1121-7.

6 Freemont AJ, Watkins A, Le Maitre C, Baird P, Jeziorska M, Knight MT, et al. Nerve growth factor expression and innervation of the painful intervertebral disc. J Pathol 2002;197:286-92.

7 Iannone F, De Bari C, Dell'Accio F, Covelli M, Patella V, Lo Bianco G, et al. Increased expression of nerve growth factor (NGF) and high affinity NGF receptor (p140 TrkA) in human osteoarthritic chondrocytes. Rheumatology (Oxford) 2002;41:1413-18.

8 Ehrhard PB, Erb P, Graumann U, Otten U. Expression of nerve growth factor and nerve growth factor receptor tyrosine kinase Trk in activated CD4-positive T-cell clones. Proc Natl Acad Sci USA 1993;90:10984-8.

9 Ehrhard PB, Ganter U, Stalder A, Bauer J, Otten U. Expression of functional trk protooncogene in human monocytes. Proc Natl Acad Sci USA 1993;90:5423-7.

10 Labouyrie E, Parrens M, de Mascarel A, Bloch B, Merlio JP. Distribution of NGF receptors in normal and pathologic human lymphoid tissues. J Neuroimmunol 1997;77:161-73.

11 Labouyrie E, Dubus P, Groppi A, Mahon FX, Ferrer J, Parrens M, et al. Expression of neurotrophins and their receptors in human bone marrow. Am J Pathol 1999;154:405-15.

12 Wu Z, Nagata K, lijima T. Immunohistochemical study of NGF and its receptors in the synovial membrane of the ankle joint of adjuvant-induced arthritic rats. Histochem Cell Biol 2000; 1 14:453-9.

13 Aloe L, Tuveri MA, Carcassi U, Levi-Montalcini R. Nerve growth factor in the synovial fluid of patients with chronic arthritis. Arthritis Rheum 1992;35:351-5.

14 Miller LE, Weidler C, Falk W, Angele P, Schaumburger J, Scholmerich J, et al. Increased prevalence of semaphorin $3 C$, a repellent of sympathetic nerve fibers, in the synovial tissue of patients with rheumatoid arthritis. Arthritis Rheum 2004;50:1156-63.

15 Weidler C, Holzer C, Harbuz M, Hofbauer R, Angele P, Schölmerich J, et al. Low density of sympathetic nerve fibers and increased density of brain-derived neurotrophic factor positive cells in RA synovium. Ann Rheum Dis 2005;64:13-20.

16 Nassenstein C, Braun A, Erpenbeck VJ, Lommatzsch M, Schmidt S, Krug N, et al. The neurotrophins nerve growth factor, brain-derived neurotrophic factor, neurotrophin-3, and neurotrophin-4 are survival and activation factors for eosinophils in patients with allergic bronchial asthma. J Exp Med 2003; 198:455-67

17 Nassenstein C, Kerzel S, Braun A. Neurotrophins and neurotrophin receptors in allergic asthma. Prog Brain Res 2004; 146:347-67.

18 Dougados M, van der Linden S, Juhlin R, Huiffeldt B, Amor B, Calin A, et al. The European Spondylarthropathy Study Group preliminary criteria for the classification of spondylarthropathy. Arthritis Rheum 1991;34:1218-30. 
19 Arnett FC, Edworthy SM, Bloch DA, McShane DJ, Fries JF, Cooper NS, et al. The American Rheumatism Association 1987 revised criteria for the classification of rheumatoid arthiritis. Arthritis Rheum 1988;31:315-24.

20 Kruithof E, Baeten D, Van den Bosch F, Mielants H, Veys EM, De Keyser F. Histological evidence that infliximab treatment leads to downregulation of inflammation and tissue remodelling of the synovial membrane in spondyloarthropathy. Ann Rheum Dis 2005;64:529-36.

21 Baeten D, Van den Bosch F, Elewaut D, Stuer A, Veys EM, De Keyser F. Needle arthroscopy of the knee with synovial biopsy sampling: technical experience in 150 patients. Clin Rheumatol 1999;18:434-41.

22 Baeten D, Kruithof E, De Rycke L, Boots AM, Mielants H, Veys EM, et al. Infiltration of the synovial membrane with macrophage subsets and polymorphonuclear cells reflects global disease activity in spondyloarthropathy. Arthritis Res Ther 2005·7:R359-69.

23 Kruith of E, Baeten D, De Rycke L, Vandooren B, Foell D, Roth J, et al. Synovial histopathology of psoriatic arthritis, oligo-and polyarticular, resembles more spondyloarthropathy than rheumatoid arthritis. Arthritis Res Ther 2005:7:569-80.

24 Baeten D, Demetter P, Cuvelier C, Van Den Bosch F, Kruithof E, Van Damme $\mathrm{N}$, et al. Comparative study of the synovial histology in rheumatoid arthritis, spondyloarthropathy, and osteoarthritis: influence of disease duration and activity. Ann Rheum Dis 2000;59:945-53.

25 Torcia M, Bracci-Laudiero L, Lucibello M, Nencioni L, Labardi D, Rubartelli A et al. Nerve growth factor is an autocrine survival factor for memory $B$ lymphocytes. Cell 1996;385:345-56.

26 Garaci E, Caroleo MC, Aloe L, Aquaro S, Piacentini M, Costa N, et al. Nerve growth factor is an autocrine factor essential for the survival of macrophages infected with HIV. Proc Natl Acad Sci USA 1999;96:14013-18.

27 Stanisz AM, Stanisz JA. Nerve growth factor and neuroimmune interactions in inflammatory diseases. Ann NY Acad Sci 2000;917:268-72.

28 Rosenfeld RD, Zeni L, Haniu M, Talvenheimo J, Radka SF, Bennett L, et al. Purification and identification of brain-derived neurotrophic factor from human serum. Protein Expr Purif 1995;6:465-71.

29 Karege F, Perret G, Bondolfi G, Schwald M, Bertschy G, Aubry JM. Decreased serum brain-derived neurotrophic factor levels in major depressed patients. Psychiatry Res 2002;109:143-8.

30 Lang UE, Hellweg R, Gallinat J. BDNF serum concentrations in healthy volunteers are associated with depression-related personality traits. Neuropsychopharmacology 2004;29:795-8.

31 Touhami A, Grueterich M, Tseng SC. The role of NGF signaling in human limbal epithelium expanded by amniotic membrane culture. Invest Ophthalmol Vis Sci 2002;43:987-94.

32 Bracci-Laudiero L, Celestino D, Starace G, Antonelli A, Lambiase A, Procoli A, et al. CD34-positive cells in human umbilical cord blood express nerve growth factor and its specific receptor TrkA. J Neuroimmunol 2003; 136:130-9.

33 Raychaudhuri SP, Sanyal M, Weltman H, Kundu-Raychaudhuri S. K252a, a high-affinity nerve growth factor receptor blocker, improves psoriasis: an in vivo study using the severe combined immunodeficient mouse-human skin model. J Invest Dermatol 2004;122:812-19. 34 Caroleo MC, Costa N, Bracci-Laudiero L, Aloe L. Human monocyte/
macrophages activate by exposure to LPS overexpress NGF and NGF receptors. J Neuroimmunol 2001;113:193-201.

35 Kawamoto K, Okada T, Kannan Y, Ushio H, Matsumoto M, Matsuda H. Nerve growth factor prevents apoptosis of rat peritoneal mast cells through the trk proto-oncogene receptor. Blood 1995;86:4638-44.

36 Baeten D, Demetter P, Cuvelier CA, Kruithof E, Van Damme N, De Vos M, et al. Macrophages expressing the scavenger receptor CD163: a link between immune alterations of the gut and synovial inflammation in spondyloarthropathy. J Pathol 2002;196:343-50.

37 Baeten D, Kruithof E, De Rycke L, Vandooren B, Wyns B, Boullart L, et al. Diagnostic classification of spondylarthropathy and rheumatoid arthritis by synovial histopathology: a prospective study in 154 consecutive patients. Arthritis Rheum 2004;50:2931-41.

38 Demetter P, De Vos M, Van Huysse JA, Baeten D, Ferdinande L, Peeters H, et al. Colon mucosa of both spondyloarthritis and Crohn's disease patients is enriched with macrophages expressing the scavenger receptor CD163. Ann Rheum Dis 2005;64:321-4.

39 De Rycke L, Baeten D, Foell D, Kruithof E, Veys EM, Roth J, et al. Differential expression and response to anti-TNFalpha treatment of infiltrating versus resident tissue macrophage subsets in autoimmune arthritis. $J$ Pathol 2005;206:17-27.

40 Reinshagen M, Rohm H, Steinkamp M, Lieb K, Geerling I, Von Herbay A, et al. Protective role of neurotrophins in experimental inflammation of the rat gut. Gastroenterology 2000;1 19:368-76.

41 Reinshagen $\mathbf{M}$, von Boyen $G$, Adler $G$, Steinkamp $M$. Role of neurotrophins in inflammation of the gut. Curr Opin Investig Drugs 2002:3:565-8.

42 Micera A, Vigneti E, Pickholtz D, Reich R, Pappo O, Bonini S, et al. Nerve growth factor displays stimulatory effects on human skin and lung fibroblasts, demonstrating a direct role for this factor in tissue repair. Proc Natl Acad Sci USA. 2001;98: 6162-7. Epub 8 May, 2001.

43 Tuveri M, Generini S, Matucci-Cerinic M, Aloe L. NGF, a useful tool in the treatment of chronic vasculitic ulcers in rheumatoid arthritis. Lancet 2000;356: 1739-40

44 Lambiase A, Manni L, Bonini S, Rama P, Micera A, Aloe L. Nerve growth factor promotes corneal healing: structural, biochemical, and molecular analyses of rat and human corneas. Invest Ophthalmol Vis Sci 2000;41:1063-9 